\title{
Clinico Diagnostic Studies on Traumatic Reticulopericarditis in Cattle - A Review of 56 Cases
}

\author{
K. Sasikala ${ }^{1}$, G. Vijayakumar $^{1 *}$, S. Sivaraman ${ }^{1}$ and G.A. Balasubramaniam ${ }^{2}$ \\ ${ }^{1}$ Department of Veterinary Clinical Medicine, ${ }^{2}$ Department of Veterinary Pathology, \\ Veterinary College and Research Institute, Namakkal 637 002, Tamilnadu Veterinary and \\ Animal Sciences University, Chennai, Tamil Nadu, India \\ *Corresponding author
}

A B S T R A C T

\begin{tabular}{|l|}
\hline K e y w o r d s \\
Cattle, \\
Radiography, \\
Ultrasonography, \\
Reticulopericarditis, \\
Therapy
\end{tabular}

Forty one Jersey cross bred and fifteen Holstein Friesian cross bred cattles were presented with the history of anorexia, pyrexia and brisket /jowl /ventral edema for 3-5 days. On clinical examination animals had tachycardia, muffled heart sounds, brisket /jowl /ventral edema, positive venous stasis, abducted elbows and pyrexia. Leukocytosis with neutrophilia, significantly elevated aspartate aminotransferase and globulin values were noticed on haemato-biochemical examination. Radiography revealed loss of thoracic details and presence of radiopaque metallic foreign body piercing the heart through diaphragm. Anechoic fluid filled pericardial cavity with or without fibrinous strands extending between walls of pericardium was appreciated through ultrasonography. Video endoscopy was done by physical restrain and could not appreciate specific changes in reticulum. 10 cattle in the near term of pregnancy were administered with streptopenicillin, frusemide, flunixin meglumine and B complex along with fluid therapy for 5 days. The pericardial drainage and lavage was done by fixing a pericardial drainage catheter. Clinical improvement was noticed on $3^{\text {rd }}$ day and were discharged on $5^{\text {th }}$ day.

\section{Introduction}

Traumatic reticulopericarditis is one of the major problems encountered in cattle resulting in greater economic loss to the farming community and causes mortality. Pericarditis is usually caused by long, thin sharp foreign bodies like binding wire, needle and nails that penetrate the reticulum, diaphragm and pericardial sac resulting in traumatic reticulopericarditis (Braun, 2009). Traumatic pericarditis is also recorded in the horse (Bertone and Dill, 1985) and in lamb (AboShehada et al., 1991). It is the most common pericardial disorder in cattle (Bexiga et al., 2008) and it is associated with progressive disturbances in heart function and almost always results in death.

Pericarditis attributable to haematogenous spread of infectious diseases (such as colibacillosis, pasteurellosis, salmonellosis 
and anaerobic infections) is much less common and is usually masked by signs of septicaemia (Grunder, 2002). Idiopathic pericarditis, which is seen in humans, dogs and horses, is rare in cattle (Jesty et al., 2005).

Pericarditis presents in three general forms; effusive, fibrinous and constrictive, although combinations of one or more of the three forms can occur (Radostits et al., 2007). In the early stages, inflammation of the pericardium is accompanied by hyperemia and the deposition of fibrinous exudate, which produces a friction sound when the pericardium and epicardium rub together during cardiac movement (Pekins et al., 2004). As effusion develops the inflamed surfaces are separated, the friction sound is replaced by muffling of the heart sounds, and the accumulated fluid compresses the atria and right ventricle, preventing their complete filling. Congestive heart failure follows.

A severe toxemia is usually present in suppurative pericarditis because of the toxins produced by the bacteria in the pericardial sac. In the recovery stage of nonsuppurative pericarditis the fluid is reabsorbed and adhesions form between the pericardium and epicardium to cause an adhesive pericarditis, but the adhesions are usually not sufficiently strong to impair cardiac movement. In suppurative pericarditis the adhesions that form become organized, starting on day 4-6 (Leak et al., 1987) and may cause complete attachment of the pericardium to the epicardium, or this may occur only in patches to leave some loculi which are filled with serous fluid (Roth and King, 1991). In either case restriction of cardiac movement will probably be followed by the appearance of congestive heart failure. Death after foreign body penetration of pericardium is usually caused by progressive fibrosive constrictive pericarditis and epicarditis, cardiac tamponade from perfora of the coronary artery has also been found (Awadhiya et al., 1974). The present paper describes clinico diagnostic studies and its management of traumatic reticulopericarditis in 56 cattle.

\section{Materials and Methods}

\section{Study area and study period}

The study was conducted in the Department of Veterinary Clinical Medicine, Veterinary College and Research Institute, Namakkal during the year 2015-16. Animals from Namakkal region and its surrounding areas were selected for the study.

\section{Selection of cases}

Forty one Jersey cross bred and fifteen Holstein Friesian cross bred cattle brought to Teaching Veterinary Clinical Complex (TVCC), Veterinary College and Research Institute, Namakkal with the history of anorexia, brisket /jowl /ventral edema and pyrexia were included in the study. Among these 56 cases all were female and were between 4 - 7 years old and weighed 250 to $350 \mathrm{~kg}$. Twenty eight of them had calved recently, nineteen of them were pregnant and nine of them were non pregnant. Animals brought for routine checkup and deworming during this period served as a control group for clinical parameters, radiography, ultrasonography and endoscopic evaluation.

\section{Clinical examination}

Clinical examination of the animal was undertaken as per standard methods (Rosenberger, 1979).

\section{Haematology}

Five milliliters of venous blood was collected in vacutainer tubes containing ethylene diamine tetra acetate (EDTA $\left.\mathrm{K}_{3}\right)$ as 
anticoagulant for haematological investigation. The parameters including packed cell volume (PCV), haemoglobin $(\mathrm{Hb})$, red blood cell (RBC), white blood cell (WBC) and differential counts (DC) were done as per standard methods (Jain, 1986).

\section{Serum biochemistry}

Five milliliters of venous blood was collected in vacutainer tubes without anticoagulant taking all precautions for avoiding haemolysis as suggested by Alleman (1990). Serum was separated and used for the estimation of aspartate aminotransferase by modified IFCC method (Bergymer, 1986), total protein by modified Biuret method and albumin by Dumans method (Varley et al., 1980) by using commercially available kits (Span diagnostics, Surat, Gujarat).

\section{Rumen fluid analysis}

All the animals under study were restrained in the chute and rumen fluid was collected by using rumen fluid extraction pump. The samples were analysed as described by Rosenberger (1979).

\section{Radiography}

All the animals under study were subjected to left lateral radiograph of caudoventral thorax and reticulum in standing posture as described by Krishnamurthy and Singh (2011) using Wipro GE 525 DX fixed $\mathrm{X}$ ray unit. The radiographic exposure of $90-110 \mathrm{kvp}, 40-$ $60 \mathrm{mAs}$ and source image distance of $100 \mathrm{~cm}$ were employed. Cassette filled with 12x15 inch blue sensitive $X$ ray film was used for radiography.

\section{Ultrasonography}

All the animals under study were subjected to ultrasonographic examination in standing position by using Esoate Mylab 40 Vet Ultrasound system and the reticulum was examined with $2.0-3.5 \mathrm{MHz}$ transducer as described by Braun and Gotz (1994).

\section{Endoscopy}

Reticuloscopy was performed using (Olympus $^{\mathrm{TM}}$ GIF V70; Olympus Corporation, Japan) flexible video endoscope with a diameter of $8 \mathrm{~mm}$ and a usable length of 150 $\mathrm{cm}$ that featured a channel for instruments (diameter $4 \mathrm{~mm}$ ) and navigation system allowing the endoscope to be moved in two directions (upward $180^{\circ}$ and downwards $100^{\circ}$ ).

Every four centimeters of the endoscope was marked with fine white lines. The instrument was equipped with a halogen light source, an irrigation system, an insufflation system and recording devices.

The use of image and data archiving system allowed digital recording of the endoscopic findings during examination. Endoscopic procedure of passing the endoscope up to oesophagus as described by Franz and Baumgartner (2002) and up to reticulum as described by Sasikala et al., (2017) was followed.

\section{Endoscopic biopsy}

Biopsy forceps was passed through the working channel of the video endoscope and the tissue sample was collected. It was stored in 10 per cent formalin and subjected to the histopathological examination as described by Bancroft and Gamble (2008).

\section{Pericardiocentesis}

A two $\mathrm{cm}$ long vertical nick was made on the skin at the fifth intercostal space on the left side at the level of point of elbow. Trocar catheter 28 FG (Romsons Scientific and 
Surgical Industry Pvt. Ltd, India) with inflated balloon was passed through this nick and slowly advanced till the pericardial exudates were evident under ultrasound guidance and the trocar was withdrawn. The catheter was fixed to the skin using Chinese finger trap suture (Fossum, 2007) and the pericardial fluid was allowed to drain (Fig. 8). The catheter was maintained for five to seven days till cessation of pericardial exudation. Pericardial cavity was lavaged with normal saline as described by Jesty et al., (2005) followed by metronidazole $(1500 \mathrm{mg})$ for 5 days.

\section{Statistical analysis}

The data obtained were statistically analyzed as described by Snedecor and Cochran (1994).

\section{Results and Discussion}

\section{Clinical examination}

The clinical signs in cattle with traumatic reticulopericarditis are given in Table 1 . The predominant clinical signs were tachycardia, tachypnoea, bruxism, brisket /jowl /ventral edema (Fig. 1), distended jugular vein, positive venous stasis (Fig. 2), pyrexia, grunting, abducted elbows and muffled heart sounds.

\section{Haemato-biochemistry}

The results of the haemato-biochemistry are given in Table 2. Leukocytosis with neutrophilia, significantly elevated aspartate aminotransferase and globulin values were predominant findings.

\section{Rumen fluid examination}

Rumen fluid examination results are given in Table 3. Sluggish rumen protozoal motility was predominant in all the cases.

\section{Radiography}

It revealed loss of thoracic details (Fig. 3) in 46.42 per cent $(26 / 56)$ of cases and presence of radiopaque metallic foreign body piercing the heart through diaphragm (Fig. 4) in 44.64 per cent (25/56) of cases (Plate 20).

\section{Ultrasonography}

Anechoic fluid filled pericardial cavity with or without fibrinous strands extending between walls of pericardium was appreciated through ultrasonography in all the cases (56/56) (Fig. $5)$.

\section{Endoscopy and biopsy}

Reticuloscopy could not appreciate specific changes in reticulum (Fig. 6). On histopathological examination reticulum showed nodular hyperplasia of stratified squamous epithelium (Fig. 7).

\section{Treatment}

Of the 56 animals with traumatic reticulopericarditis only 10 owners of cattle in the near term of pregnancy accepted for treatment. These cases were administered with streptopenicillin (@5 g IM twice daily), frusemide (@2 mg/kg IM twice daily), flunixin meglumine $(@ 2.2 \mathrm{mg} / \mathrm{kg}$ IM twice daily) and B complex (@10 ml IM twice daily) along with fluid therapy (DNS @5 $\mathrm{ml} / \mathrm{kg}$ IV twice daily) for 5 days. Pericardial drainage catheter was fixed and lavaged.

The effusion reduced by $3^{\text {rd }}$ day and the catheter was removed on $5^{\text {th }}$ day. Clinical improvement was noticed on $3^{\text {rd }}$ day and was discharged on $5^{\text {th }}$ day. Then cattle were followed up to calving and six animals had calved normally but subsequently developed severe signs of congestive heart failure, while four animals died before calving. 
Table.1 Clinical manifestations in cattle with traumatic reticulopericarditis (\%)

\begin{tabular}{|c|l|c|c|}
\hline SI. No & \multicolumn{1}{|c|}{ Clinical signs } & Number & $\begin{array}{c}\text { Traumatic } \\
\text { reticulopericarditis (n=56) }\end{array}$ \\
\hline 1. & Abducted elbows & 38 & 67.85 \\
\hline 2. & Anorexia & 52 & 92.85 \\
\hline 3. & Arched back & 38 & 67.85 \\
\hline 4. & Brisket / jowl edema & 52 & 92.85 \\
\hline 6. & Bruxism & 54 & 96.42 \\
\hline 7. & Diarrhoea & 4 & 7.14 \\
\hline 8. & Distended jugular veins & 52 & 92.85 \\
\hline 9. & Grunting & 42 & 75.00 \\
\hline 10. & Hypermotility of rumen & 0 & 0.00 \\
\hline 11. & Marked drop in milk yield & 50 & 89.28 \\
\hline 12. & Muffled heart sounds & 34 & 60.71 \\
\hline 13. & Positive venous stasis & 52 & 92.85 \\
\hline 14. & Pyrexia & 52 & 92.85 \\
\hline 15. & Recurrent tympany & 12 & 21.42 \\
\hline 16. & Recumbency & 19 & 33.92 \\
\hline 17. & Regurgitation & 0 & 0.00 \\
\hline 18. & Ruminal atony & 52 & 92.85 \\
\hline 19. & Scanty faeces & 48 & 85.71 \\
\hline 20. & Tachypnoea & 54 & 96.42 \\
\hline 21. & Tachycardia & 56 & 100.00 \\
\hline
\end{tabular}

Table.2 Haemato-biochemistry in apparently healthy cattle and cattle with traumatic reticulopericarditis

\begin{tabular}{|c|c|c|c|c|}
\hline $\begin{array}{l}\text { Sl. } \\
\text { No }\end{array}$ & Parameters & $\begin{array}{c}\text { Apparently } \\
\text { healthy cattle } \\
(n=20) \\
\text { Mean } \pm \text { SE }\end{array}$ & $\begin{array}{c}\text { Traumatic } \\
\text { reticulopericarditis } \\
(\mathrm{n}=\mathbf{2 0}) \\
\text { Mean } \pm \text { SE }\end{array}$ & Indication \\
\hline 1. & Haemoglobin (g/dl) & $11.20 \pm 0.09$ & $11.35 \pm 0.19$ & Normal \\
\hline 2. & Packed cell volume (\%) & $34.35 \pm 0.46$ & $34.05 \pm 0.58$ & Normal \\
\hline 3. & Red Blood cell count (10\% cumm) & $6.47 \pm 0.08$ & $6.48 \pm 0.09$ & Normal \\
\hline 4. & White blood cell count $\left(10^{3} /\right.$ cumm $)$ & $6.58^{\mathrm{a}} \pm 0.11$ & $18.19^{b} \pm 0.50$ & Elevated \\
\hline 5. & Neutrophils $\left(10^{3} /\right.$ cumm $)$ & $2.24^{\mathrm{a}} \pm 0.05$ & $13.73^{\mathrm{b}} \pm 0.43$ & Elevated \\
\hline 6. & Lymphocytes (103/cumm) & $4.31 \pm 0.07$ & $4.48 \pm 0.14$ & Normal \\
\hline 7. & Monocytes $\left(10^{3} /\right.$ cumm $)$ & $0.13 \pm 0.06$ & $0.09 \pm 0.09$ & Normal \\
\hline 8. & Eosinophils ( $10^{3} /$ cumm $)$ & $0.07 \pm 0.04$ & $0.16 \pm 0.51$ & Normal \\
\hline 9. & Aspartate amino transferase (AST) (units/L) & $100.45^{\mathrm{a}} \pm 2.85$ & $159.80^{\mathrm{b}} \pm 6.43$ & Elevated \\
\hline 10. & Total protein $(\mathrm{g} / \mathrm{dL})$ & $6.28 \pm 0.23$ & $7.83 \pm 0.22$ & Normal \\
\hline 11. & Albumin $(\mathrm{g} / \mathrm{dL})$ & $2.98 \pm 0.05$ & $2.54 \pm 0.07$ & Normal \\
\hline 12. & Globulin (g/dL) & $3.30^{\mathrm{a}} \pm 0.22$ & $5.29^{c} \pm 0.22$ & Elevated \\
\hline
\end{tabular}

Note: Mean bearing same superscript in same row does not differ significantly 
Table.3 Rumen fluid analysis in apparently healthy cattle and cattle with traumatic reticulopericarditis

\begin{tabular}{|c|c|c|c|c|}
\hline Sl. No & \multicolumn{2}{|c|}{ Parameters } & $\begin{array}{l}\text { Apparently } \\
\text { healthy cattle } \\
\quad(n=20)\end{array}$ & $\begin{array}{c}\text { Traumatic } \\
\text { reticulopericarditis } \\
(n=20)\end{array}$ \\
\hline 1. & \multicolumn{2}{|l|}{ Colour } & Yellowish to brown & Yellowish to brown \\
\hline 2. & \multicolumn{2}{|c|}{ Consistency } & Slightly viscous & Watery \\
\hline 3. & \multicolumn{2}{|c|}{ Odour } & Aromatic & Aromatic \\
\hline 4. & \multicolumn{2}{|c|}{ SAT (min) } & $4.33^{b} \pm 0.21$ & $2.83^{\mathrm{a}} \pm 0.54$ \\
\hline 5. & \multicolumn{2}{|c|}{$\mathrm{pH}$} & $6.48^{b} \pm 0.11$ & $6.58^{b} \pm 0.11$ \\
\hline 6. & \multicolumn{2}{|c|}{ MBRT (min) } & $2.50^{\mathrm{a}} \pm 0.22$ & $6.83^{b} \pm 0.47$ \\
\hline 7. & \multicolumn{2}{|c|}{ Titratable acidity (units) } & $17.50^{\mathrm{a}} \pm 1.11$ & $17.50^{\mathrm{a}} \pm 1.11$ \\
\hline \multirow[t]{2}{*}{8.} & \multirow[t]{2}{*}{ Protozoa } & Size & Medium and Small & Nil \\
\hline & & Density & ++ & Nil \\
\hline 9. & \multicolumn{2}{|c|}{ Iodophilic activity } & +++ & + \\
\hline
\end{tabular}

Note: Mean bearing same superscript in same row do not differ significantly

\begin{tabular}{|l|l|}
\hline Fig.1 Brisket /jowl /ventral edema & Fig.2 Engorged jugular vein and positive \\
\hline venous stasis
\end{tabular}




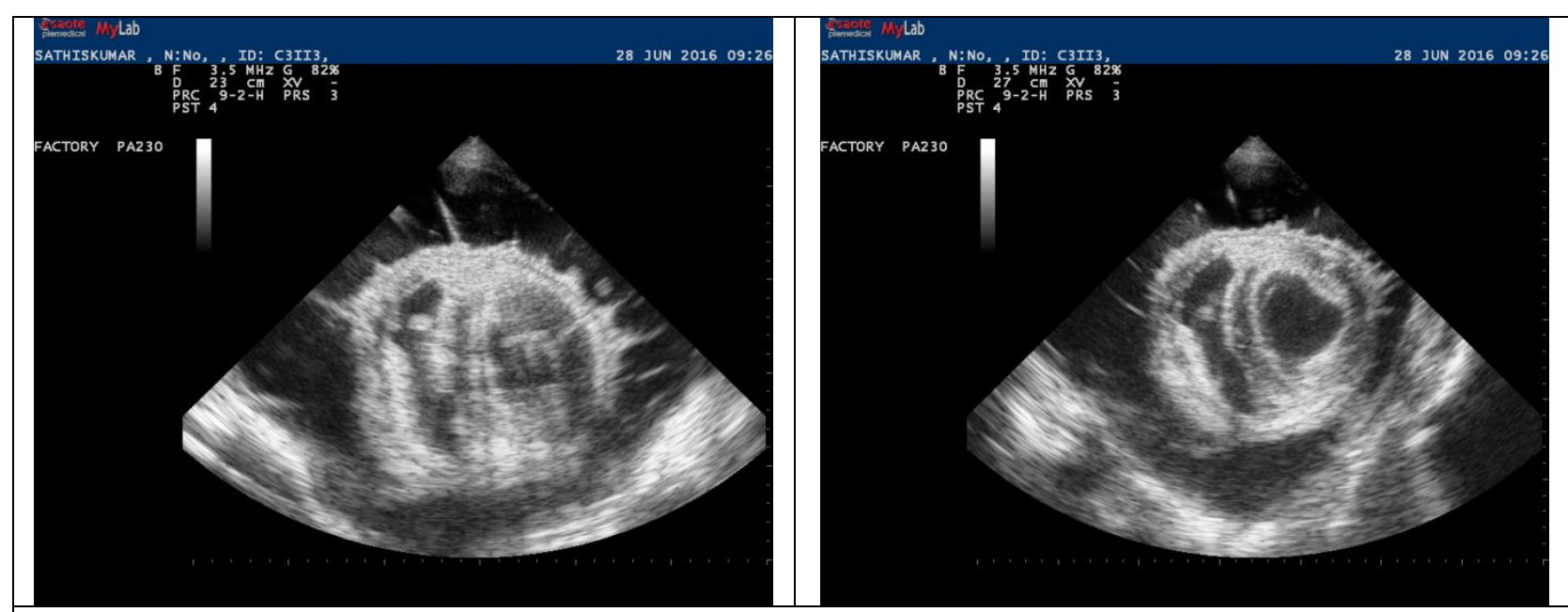

Fig.5 Anechoic fluid surrounding the myocardium with fibrinous strands extending between the pericardial walls

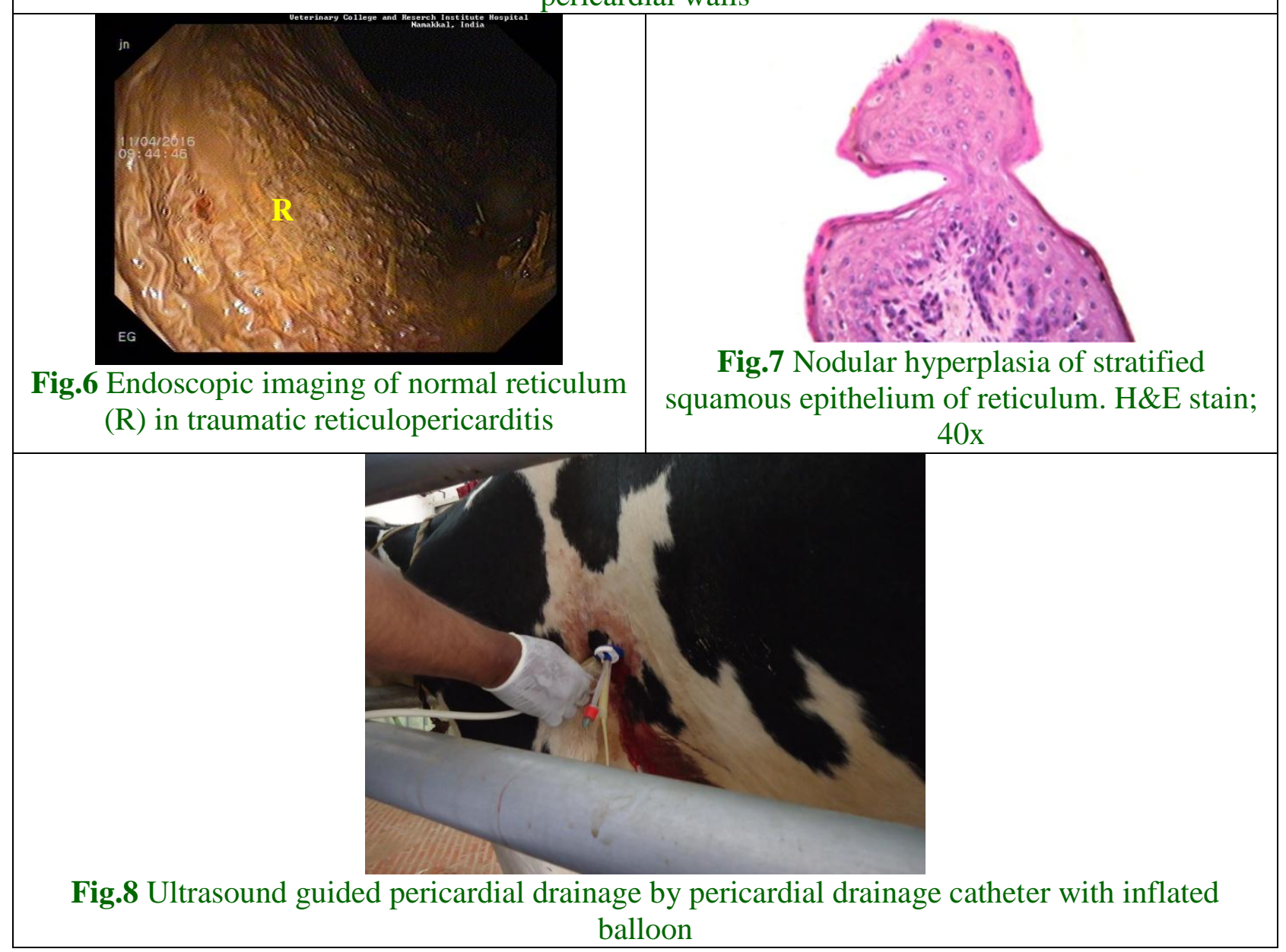

Cattle are more susceptible to foreign body syndrome, due to lack of oral discrimination. Pericarditis is the inflammation of both parietal and visceral surfaces of the pericardium with accumulation of serous or fibrous inflammatory products (Reef and McGuirk, 2009). It is associated with progressive disturbances in cardiac function and almost always results in death (Braun, 2009). Athar et al., (2012) reported higher 
incidence of traumatic pericarditis and hepatic congestion in female cattle and buffaloes which were in advanced stage of pregnancy and calved recently. Idiopathic fibrinous pericarditis in an eight years old Nili-Ravi buffalo was reported by Sharma et al., (2012).

\section{Clinical examination}

Tachycardia, tachypnoea, muffled heart sounds, bruxism, distended jugular vein, positive venous stasis, brisket and / or ventral edema, abducted elbows, bruxism, pyrexia and grunting were observed in cattle with traumatic reticulopericarditis (Radostits et al., 2007; Braun, 2009; Sharma et al., 2012). Mohamed (2010) recorded presternal oedema, abnormal heart sounds, jugular, mammary vein distension and pulsation and positive for various pain tests in buffaloes with traumatic pericarditis. Tachycardia, muffled heart sounds, distended jugular veins, pericardial sounds like splashing, rubbing or squeaking sounds, brisket and ventral oedema were observed in cattle with traumatic reticulopericarditis (Ramin et al., 2011). Tharwat (2011) observed anorexia, recurrent tympany, presternal and ventral oedema and diarrhoea in cattle with traumatic pericarditis. Similar clinical findings were observed in the present study.

\section{Haemato-biochemistry}

Leukocytosis with neutrophilia and elevated levels of aspartate aminotransferase and globulin values were in agreement with the previous studies (Sharma et al., 2012; Habasha and Yassein, 2014). Marked leukocytosis with neutrophilia, as well as hyperglobulinemia are usually present in cattle with traumatic pericarditis (Radostits $e t$ al., 2007). Increase in total leukocyte count with neutrophilic leukocytosis, lowered A/G ratio due to decreased albumin and increased globulin levels were noticed in animals with traumatic pericarditis (Athar et al., 2011). These changes were often a reflection of cellular destruction and inflammatory response to foreign bodies.

\section{Rumen fluid examination}

Reddy et al., (2014) recorded viscous rumen fluid, pH 7.0 and 'single +' protozoal concentration with sluggish motility in cattle with traumatic reticuloperitonitis / pericarditis. Similar changes were noticed in the present study.

\section{Radiography}

In the present study, radio-opaque foreign bodies could be appreciated radiographically only in 44.64 per cent of animals. This could be due to the insufficient density of the foreign bodies to be visualized in the radiograph and owing to the increased thickness of the thorax / abdomen of the cattle. Khalphallah et al., (2015) reported that radiography failed to identify inflammatory changes that occurred on the reticular serosa or failed to show any abnormalities in the heart / reticulum. Radiography was the best method for visualizing the metallic foreign bodies in and outside the reticulum and the position of the foreign body was not a reliable indicator of the condition (Braun et al., 1993). Visualization of foreign body within the reticulum in some of the cases in the present study was in concurrence with reports of Braun et al., (1993). Loss of details in radiography of cattle with traumatic pericarditis could be due to the presence of large amounts of fibrinous exudates in the pericardial sac.

\section{Ultrasonography}

Ultrasonographic findings in traumatic reticulopericarditis were represented as mixed echogenicities in the pericardial sac. This 
might be due to the presence of turbid pericardial fluid, which in more progressive cases of pericarditis, appeared as extensive hyperechoic strands in the pericardial sac. Ultrasonographic examination revealed presence of large network representing fibrin, fibrinous exudates and fluid in pericardial sac in the traumatic pericarditis and affecting the basic cardiac function (Braun, 2009; Danjuma et al., 2014).

\section{Endoscopy and biopsy}

Endoscopic imaging is highly useful for the diagnosis of intraluminal changes associated with diseases of reticulum in cattle. On histopathology reticulum showed nodular hyperplasia of stratified squamous epithelium. Similar changes were noticed by Maxie (2016) in cattle with traumatic reticulopericarditis.

\section{Therapy}

Broad spectrum antibiotics, pericardiocentesis, pericardial lavage and non-steroidal anti-inflammatory drugs were effectively used for the management of traumatic reticulopericarditis (Radostits et al., 2007).

Reef and McGuirk (2009) reported that treatment of traumatic pericarditis was unrewarding in cattle and usually was addressed toward salvage or short term survival to calving.

The observations in the present study were supported by the reports of Radostits et al., (2007) and Reef and McGuirk (2009).

Ultrasonography was able to diagnose traumatic reticulopericarditis effectively. It is complementary to clinical, radiographic and endoscopic evaluation in cattle with traumatic reticulopericarditis.

\section{Acknowledgement}

The authors are very thankful to the Dean, Veterinary College and Research Institute, Namakkal for the facilities provided during the study.

\section{References}

Abo-Shehada, M.N., Al-Rawashdeh, O., and Al-Natour, M. 1991.Traumatic pericarditis in an Awassi lamb. Br. Vet. J., 147(1): 78-81.

Alleman, A. R., 1990. The effects of haemolysis and lipemia on serum biochemical constituents. Vet. Med., 89: 1272-1284.

Athar, H., Mohindroo, J., Randhawa, C. S., Singh, K. and Saini, N. S. 2011. Clinical, haemato biochemical, radiographic and ultrasonographic findings in bovines suffering from pericarditis and pleural effusions. Indian J. Anim. Sci., 81: 48.

Athar, H., Parrah, J. D., Moulvi, B. A., Singh, M. and Dedmari, F. H. 2012. Pericarditis in bovines - A review. Intern. J. Adv. Vet. Sci. Tech., 1: 19-27.

Awadhiya, R.P., Kolte, G.N. and Vegad, J.L. 1974. Cardiac Tamponade: A Fatal Complication of Traumatic Reticulitis in Cattle. Vet Rec. 95: 260-262.

Bancroft, J.D. and Gamble, M. 2008. Theory and practice of histological techniques. $6^{\text {th }}$ edn., Churchill Livingstone, London. pp. 75-82.

Bergymer, H. U., 1986. Approved recommendation of IFCC method for measurement of catalytic concentration of enzymes. Part 2. IFCC methods for aspartate amino transferase. J. Clin. Chem. Clin. Biochem, 24: 497-510.

Bertone, J.J. and Dill, S.G. 1985. Traumatic gastropericarditis in a horse. J. Am. Vet. Med. Assoc. (USA). 187: 742-743. 
Bexiga, R., Mateus, A., Philbey, A.W., Ellis, K., Barrett, D.C., and Mellor. D.J. 2008. Clinicopathological Presentation of Cardiac Disease in Cattle and Its Impact on Decision Making. Vet Rec. 162: 575-80.

Braun, U. and Gotz, M. 1994. Ultrasonography of the reticulum in cows. Am. J. Vet. Res., 55: 325-332.

Braun, U., Fluckiger, M. and Nageli, F. 1993. Radiography as an aid in the diagnosis of traumatic reticuloperitonitis in cattle. Vet. Rec., 132: 103-109.

Braun. U. 2009. Traumatic pericarditis in cattle: Clinical, radiographic and ultrasonographic findings. Vet. J., 182: 176-186.

Danjuma, F.A., Otolorin, G.R., Mshalbwala, P.P. and Abubakar, A. 2014. Acute traumatic pericarditis in a $4-8$ years old Bunaji bull: A case report. Res., 1: 960.

Fossum, T.W., 2007. Small Animal Surgery, Mosby Elsevier, USA. pp. 103.

Franz, S. and Baumgartner, W. 2002. A retrospective study of oesophageal endoscopy in cattle and oesophagoscopy for diagnosis of mucosal disease. Vet. J., 163: 205-210.

Grunder, H.D., 2002. Krankheiten des Herzens und des Herzbeutels. In: Dirksen, G., Grunder, H.D., Stober, M. (Eds.), Innere Medizin und Chirurgie des Rindes, fourth ed. Parey Buchverlag, Berlin, pp. 159-181.

Habasha, F.G. and Yassein, S.N. 2014. Advance techniques in traumatic reticuloperitonitis diagnosis: A review. Al-Qadisiya J. Vet. Med. Sci., 13: 5057.

Jain, N. S., 1986. Haematological techniques. In: Schalm's Veterinary Haematology. $4^{\text {th }}$ edn., Lea and Febiger, Philadelphia. pp. 20-86.

Jesty, S.A., Sweeney, R.W., Dolente, B.A. and Reef, V.B., 2005. Idiopathic pericarditis and cardiac tamponade in two cows. Journal of the Am. Vet. Med. Assoc., 226, 1555-1558.

Khalphallah, A.A., El-Sebaie, A.H. and Raghib, M.F. 2015. Approach for diagnosis of complicated traumatic reticuloperitonitis in cattle using ultrasonography. J. Adv. Vet. Res., 5: 157-164.

Krishnamurthy, D. and Singh, A.P. 2011. Contrast techniques. In: Singh, J (ed): Veterinary radiology. Basic principles and radiographic positioning. CBC publishers, New Delhi. pp. 184-189.

Leak, L.V., Ferrans, V.J., Cohen, S.R., Eidbo, E.E. and Jones, M. 1987. Animal model of acute pericarditis and its progression to pericardial fibrosis and adhesions: ultrastructural studies. Am J Anat., 180: 373-90.

Maxie, M.G. 2016. Jubb, Kennedy and Palmer's: Pathology of domestic animals. $6^{\text {th }}$ edn, Elsevier, St. Louis, Missouri. pp. 35-43.

Mohamed, T., 2010. Clinicopathological and ultrasonographic findings in 40 water buffaloes (Bubalus bubalis) with traumatic pericarditis. Vet. Rec., 167: 819-824.

Pekins, S.L., Magdesian, K. G., Thomas, W. P. and Spier, S. J. 2004. Pericarditis and Pleuritis Caused By C. Pseudotuberculosis in a Horse. $\mathbf{J}$ Am Vet Med Assoc., 224: 1133-1138.

Radostits, O.M., Gay, C.C., Hinchcliff, K.W. and Constable, P.D. 2007. Veterinary Medicine. A textbook of the diseases of cattle, horses, sheep, pigs and goats. $10^{\text {th }}$ edn., W.B. Saunders Elsevier, Philadelphia. pp. 211-215.

Ramin, A. G., Hashemi, A. M., Asri-Rezaie, S., Batebi, E., Tamadona, A. and Ramin, S. 2011. Prediction of traumatic pericarditis in cows using some serum biochemical and enzyme parameters. Acta. Vet., 61: 383-390. 
Reddy, B. S., Reddy, L. S. S. V. Sivajothi, S. and Reddy, B. S. 2014. Traumatic reticuloperitonitis in cattle: A clinical study. Intern. Sci. World., 2: 13-15.

Reef, V.B., and McGuirk, S.M. 2009: Diseases of Cardiovascular System. In: Smith B.P. (Ed). Large Animals Internal Medicine, 4th Ed., Mosby Inc. Philadelphia, USA, 474-478.

Rosenberger, G., 1979. Clinical examination of cattle. $2^{\text {nd }}$ edn, Verlag Paul Parey, Berlin and Hamburg, Germany. pp. 184-212.

Roth, L. and King, J.M. 1991. Traumatic reticulitis in cattle: a review of 60 fatal cases. J. Vet. Diag. Invest., 3: 52.

Sasikala, K., Vijayakumar, G., and Balasubramaniam, G.A., 2017.
Endoscopic Evaluation of Reticulum in Cattle - A Preliminary Study. Indian Vet. J., 94 (05): $79-80$.

Sharma, S., Gosal, N.S. and Varun. 2012. Idiopathic fibrinous pericarditis in a Nili-Ravi buffalo. Buffalo Bulletin, 31: 171-175.

Snedecor, G. W. and W. G Cochran, 1994. Statistical methods. $8^{\text {th }}$ edn., Iowa State University Press, Ames, Iowa.

Tharwat, M., 2011. Traumatic pericarditis in cattle: Sonographic, echocardiographic and pathologic findings. J. Agri. Vet. Sci., 4: 45-59.

Varley, H., Grawlock, A. H. and Bell, M. 1980. Practical Clinical Biochemistry. Vol. I. $5^{\text {th }}$ edn., William Heinmann Medical Books Ltd., London, pp. 186.

\section{How to cite this article:}

Sasikala, K., G. Vijayakumar, S. Sivaraman and Balasubramaniam, G.A. 2018. Clinico Diagnostic Studies on Traumatic Reticulopericarditis in Cattle - A Review of 56 Cases. Int.J.Curr.Microbiol.App.Sci. 7(05): 513-523. doi: https://doi.org/10.20546/ijcmas.2018.705.065 